A century of Armistice Day: memorialisation in the wake of the First World War Jenny Macleod and Yvonne Inall

(JM) History, School of Histories, Languages, and Cultures, University of Hull, Hull, United Kingdom

(YI) Geography, School of Environmental Sciences, University of Hull, Hull, United Kingdom

Corresponding author: Dr Jenny Macleod

Postal address: SHLC, University of Hull, Cottingham Road, Hull, HU6 7RX

Telephone: 01482465833

Email: $\underline{\text { J.Macleod@hull.ac.uk }}$

Twitter: @JennyMacleod

Orcid: 0000-0001-5277-7063

This is an Accepted Manuscript of an article published by Taylor \& Francis in Mortality on 23 May 2019, available online: https://www.tandfonline.com/doi/full/10.1080/13576275.2019.1611752.

Biographical note

Dr Jenny Macleod is a Senior Lecturer in $20^{\text {th }}$ Century History at the University of Hull. She has written a number of books and articles on the memory of the First World War, commemoration, war memorials, and Britishness. Her most recent book, Gallipoli: Great Battles (Oxford University Press, 2015) examined Anzac Day (and its equivalents) in Britain, Ireland, Australia, New Zealand and Turkey to explore the relationship between commemoration and national identity.

Dr Yvonne Inall is a Postdoctoral Research Associate on the AHRC-funded project 'Remember Me: The Changing Face of Memorialisation'. As an archaeologist, she has been exploring approaches to memorialisation from a Deep Time perspective. Her research interests include violence and commemoration, Iron Age warfare and the construction of martial identities.

Funding details and Acknowledgements 
The initial survey of newspaper articles upon which this article is based was conducted by Dr Yvonne Inall as part of the UK Arts and Humanities Research Council (ref. AH/M008398/1). The author(s) are grateful to colleagues on the 'Remember Me' team - Emeritus Professor Margaret Holloway (PI), Dr Lisa Dikomitis (Cl), Dr Nicholas Evans (Cl), Professor Malcolm Lillie (Cl), Assoc. Professor Liz Nicol (Cl), Rev Dr Andrew Goodhead (project collaborator), Dr Louis Bailey (RF) Dr Miroslava Hukelova (RF), Dr Yvonne Inall (RF), and Dr Michael S. Drake $(\mathrm{Cl})\left({ }^{\dagger}\right)^{1}$ - for their shared insights. Furthermore, the authors are grateful to the two anonymous reviewers, Dr Helen McCartney, Professor Holloway and Professor Lillie for their constructive comments on earlier drafts of this article.

1 Deceased 28.8.2017 


\title{
A century of Armistice Day: memorialisation in the wake of the First World War
}

\begin{abstract}
In the wake of the First World War a set of commemorative traditions were invented that were met with a huge public response and were repeated in almost every subsequent November. These apparently unchanging traditions were reported in the media each year in ways that reflected the, then, present circumstances. This article explores the ideas of continuity and relevance as a means to chart the changing nature of public debate about the commemoration of war in Britain. It will consider three broad periods: inter-war, the Second World War and post-war decades, and the 1980s to the centenary years. It will argue that the commemorations were fiercely relevant in the inter-war period demonstrated by the attendance of huge crowds and extensive newspaper coverage which related the ceremonies to contemporary events. When official commemorations resumed in 1946 limited changes were made and newspaper coverage was much reduced and more abstract: it spoke far less directly to the experiences and emotional legacy of the Second World War, and the habit of reporting on the commemorations diminished significantly in this period. The turning point appears to have been the 1980 s wherein social and generational change, plus a series of poignant anniversaries and pilgrimages served to make commemoration emotionally and politically relevant once more such that by the late 1990s a renewed interest was widely noted. The sustained period of warfare from 2001 onwards added further to this.
\end{abstract}

Keywords: commemoration, Armistice Day, Remembrance Sunday, First World War, Second World War, Korean War, Afghanistan, centenary 
The Times' editorial on 11 November 1938, 'Twenty Years After' began,

A wise instinct has kept the ceremonial of Armistice Day without alteration, and indeed its unfailing impressiveness is largely due to its unchanged simplicity. Yet, while the method of observance does not vary from year to year, the Day itself always seems to take on some new shade of meaning from the circumstances in which it finds us.

In the wake of the First World War a set of commemorative traditions were invented that were met with a huge public response and were repeated in almost every subsequent November. These traditions were the silence, the Cenotaph, the Unknown Warrior, and the poppy. These apparently unchanging traditions were reported in the media each year in ways that reflected the, then, present circumstances. This article explores the twin ideas from this 1938 editorial, continuity and relevance, as a means to chart the changing nature of public debate about the commemoration of war in Britain. It will consider three broad periods: (1) inter-war, (2) the Second World War (hereafter WW2) and post-war decades, and (3) the 1980s to the centenary years. It will argue that the commemorations were fiercely relevant in the inter-war period demonstrated by the attendance of huge crowds and extensive newspaper coverage which related the ceremonies to contemporary events. Yet the precise nature of the relevance of the occasion was open to interpretation according to political preferences. When official commemorations resumed in 1946 limited changes were made and newspaper coverage was much reduced and more abstract: it spoke far less directly to the experiences and emotional legacy of the Second World War, and the habit of reporting on the commemorations diminished significantly in this period. The turning point appears to have been the 1980s wherein social and generational change, plus a series of poignant anniversaries and pilgrimages served to make commemoration emotionally and politically relevant once more such that by the late 1990s a renewed interest was widely noted. The sustained period of warfare from 2001 onwards added further to this.

The historiography of this subject mirrors the revival of interest in commemoration amongst the general public. A small number of pioneers demonstrated the potential of the subject, notably Ken Inglis $(1965,1992,1998)$ and George Mosse $(1979)$, who paved the way for the 1990s boom in the study of commemoration. The most significant amongst these were Adrian Gregory's close examination of the two minutes' silence (1994) in Britain up to the end of the Second World War and Jay Winter's wide-ranging Sites of Memory, Sites of Mourning (1995) which argued for the importance of traditional modes and ideas, particularly those derived from religion, within the remembrance of war. Within the cohort of historians inspired by these works, Dan Todman's study of the changing views of the war in Britain amongst the generations who followed is outstanding for the way it contextualises shifting attitudes within social change and family dynamics over ninety years (Todman, 2005; see also Holbrook, 2014; Macleod, 2002 \& 2015). The historiographical interest in war memorials and commemoration was part of a wider cultural turn that explored memory and history, and the intersections of private and collective remembrance. It drew upon what Winter (2006) terms a 'memory boom' in Western culture, which gave a privileged position to the 'witness' to historical events in their remembrance. It will be seen that the role of the witness became a belated part of the newspaper coverage of war commemoration in Britain. 


\section{How important was Armistice Day?}

This article aims to provide a longitudinal study of the public discourse around Armistice Day and Remembrance Sunday. It is based on a sample of newspaper articles from the left-leaning Manchester Guardian ${ }^{1}$ and the right of centre The Times, chosen for political balance and their national readership. Digitised newspaper databases ${ }^{2}$ offer the possibility of tracking the changing relevance of the day quantitatively as well as the more familiar qualitative approach. The number of newspaper articles mentioning Armistice Day and Remembrance Day will be taken as a proxy for their prominence in national life. First, to establish the November commemorations' overall importance, Figure 1 compares the number of articles about other great national occasions occurring annually on a single day: Burns Night, Empire Day, Anzac Day, VE Day (marking Victory in Europe in the Second World War), Trooping the Colour, VJ Day (Victory in Japan), Trafalgar Day, Armistice Day, Remembrance Sunday, and the State Opening of Parliament. Even without aggregating Armistice Day and Remembrance Sunday, it is clear that Armistice Day received by far the most newspaper coverage overall. Thus, Armistice Day on its own and in combination with its successor was the most important national annual event. It dwarfs the only other First World Warrelated anniversary in the sample, Anzac Day, and it appears to dwarf the Second World War-specific VE Day and VJ Day.

However, the prominence of these national anniversaries did not remain steady across the century. This can be explored in a number of ways. Firstly, if we consider how the newspaper coverage is split between the three periods: up to the end of the Second World War (1919-45), from the resumption of commemoration until 1979, and from 1980 to the present. This reflects trends that might be expected: Armistice Day drops away in 1946 as Remembrance Sunday begins, and, of course, VE Day and VJ Day are shown to be post-WW2 phenomena. More surprisingly, they are shown to be particularly reported on after 1980. On a side note, Empire Day is shown to have been a pre-WW2 phenomenon, but Burns Night (and hence, perhaps, Scottish nationalism) only became widely discussed after 1980. Looking more closely at the number of articles about the November commemorations reveals that by far the greatest number of newspaper articles on this subject were published in the first two decades after the end of the First World War. Figure 2 indicates that newspaper coverage of Armistice Day peaked in the late 1920s with the tenth anniversary of the War's end. The coverage of the event stabilised at a lower level in the 1930s and then declined dramatically during the Second World War and remained in the doldrums until a slow revival from the early 1980s that gathered pace in the late 1990s and grew significantly again in the last ten years. Within this overall context, this article will now investigate how Armistice Day was shaped as

\footnotetext{
${ }^{1}$ The publication's name was changed to The Guardian in 1959. The database used also includes the Sunday newspaper, The Observer. Broad numerical discussions will use 'The Guardian' to also include The Manchester Guardian and The Observer.

${ }^{2}$ The newspapers are available in three databases, ProQuest Historical Newspapers: The Guardian and The Observer which covers 1791 to 2003, The Times Digital Archive 1785-2012, and LexisLibrary which includes all three newspapers from 1984/5 to present.
} 
a response to the First World War and the extent to which it maintained its continuity and relevance post-Second World War.

\section{Armistice Day: the origins of a tradition}

Between 4 August 1914 and 11 November 1918, the United Kingdom raised a mass army for the first time in its history to fight in a global war which was characterised above all by industrialized warfare and particularly the use of high explosive artillery shells. The sustained use of weapons of such destructive force led to terrible losses for all participant nations. The British Empire's dead approached one million, of whom those from the British Isles comprised more than 700,000. Many of their bodies remain missing or unnamed to this day due to the effects of artillery. The dead were young men in their prime whose deaths occurred at a novel moment in public health improvements and improved nutrition when parents could otherwise reasonably have expected their children to outlive them (Jalland, 2010, p. 8). This was an unprecedented scale of sustained and nation-wide loss at the time and has been unmatched since. Estimates differ as to what this meant in terms of the extent of family bereavements. Even a conservative estimate suggests ten per cent of the population lost a close relative, and accepts that connections to the fallen in the extended family would have meant 'universal bereavement' (Gregory, 2008, p. 253; see also Richardson, 1998, p. 353). What can be said with confidence is that the war inflicted deep emotional wounds.

It also had profound political consequences. A sense of the turbulence created can be derived from some of the developments in the months following the armistice. This period saw the first UK general election where all men and some women could vote, the outbreak of the Irish War of Independence which led to the break-up of the United Kingdom, a mutiny amongst demobilizing British soldiers in France, and a series of race riots in Britain's ports fuelled by unemployment amongst returning soldiers (Jenkinson, 2008). Across Europe and beyond, the picture was even more disrupted with wars and revolutions which lasted into 1923 following in the wake of the break-up of four empires: Austria-Hungary, Germany, Russia and the Ottoman Empire. Whilst it is now clear that Britain (but not Ireland) witnessed a decrease in political violence in the post-war period, (Edele \& Gerwarth, 2015, p. 5) the broader picture of disruption nonetheless provides an important part of the context in which the unifying rituals were developed. It will be seen that The Times was particularly keen to identify the unity of those remembering the war.

During the war the customary rituals in response to death had been adapted and developed by individuals in the private spaces of their homes and by local communities to remember the dead and to honour their sacrifices, particularly through street shrines (Connelly, 2002, p. 25; Foster, 2018; King, 1998, p. 60). The experience and practices of wartime fed directly into commemoration post-war. The mass volunteer army recruited through the bonds of civil society was commemorated as such at the local level through a war memorial movement that rapidly gathered pace during 1919. 
From 1916 onwards, this unprecedented mobilisation was reinforced by Britain's first ever use of conscription, ensuring that the war touched the lives of even more young men, and military service became even more national in scope. The erection of a 'temporary shrine' in Whitehall at the insistence of David Lloyd George, the Liberal Prime Minister in a Conservative-dominated coalition government, as part of the Peace Day celebrations organized by Lord Curzon on 19 July 1919 was a reflection of the widespread commitment to commemoration that was already in place (King, 1998, p. 15; Cannadine, p. 220). On the first anniversary of the armistice, this Cenotaph formed the centrepiece of the national commemoration along with the innovation of the two minutes' silence. Following a proposal to the Cabinet by Sir Percy Fitzpatrick, former High Commissioner in South Africa, what had begun as a daily wartime habit in the Dominion was established empire-wide by royal decree in 1919 (Gregory 1994, p.9; 'The Glorious Dead', 1919) as a conscious echo of the moment the guns had fallen silent a year earlier at 11am on 11 November. On Armistice Day 1920, the permanent version of the Cenotaph was unveiled and immediately afterwards, the Unknown Warrior was buried at Westminster Abbey. The arrangements had been a matter of close interest to the Cabinet, and the details of the ceremony at Sir Edwin Lutyens' design for the Cenotaph were formulated by a committee led by Lord Curzon, the Foreign Secretary, with input from, amongst others, Alfred Mond, the First Commissioner of Works, Sir Lionel Earle, Permanent Secretary at His Majesty's Office of Works, Dean Ryle of Westminster Abbey, General George Jeffreys, GOC London, and the King himself (Cannadine, 1981; Heathorn 2008; TNA WORK 20/1/3). Thus, this powerful triumvirate of traditions: the silence, the Cenotaph, and the Unknown Warrior were coordinated by politicians and clerics, enacted by the military led by the Head of State, and met by overwhelming support from the public. Commemoration was driven by an emotional need from below to process grief. It is also possible to infer a political imperative from above: the newspaper coverage of commemoration indicates a sustained effort to convey a meaningful political message about the worthwhile nature of the cause in which so many had died.

At the heart of these new commemorative traditions lay the relationship between individual experience and the unity of the whole: the millions of stories of personal bereavement and the shared acknowledgement of that at the national level. The two minutes' silence was the perfect expression of this: a prayer-like moment for the individual made powerful by the shared experience of quietude amongst a crowd. The Manchester Guardian reported the two minutes in Whitehall as

A silence different from any we have known. The tension of this great multitude acting and reacting on one another must have created strange psychic experiences. What a volume of human yearning must have been going into the void; how terrible the projection of longing from the living to those who no longer lived ('The Silent Commemoration', 1919).

The silence reflected profound individual pain and its acknowledgement by the nation through a unifying gesture. A similar dynamic underpinned the powerful emotional force of the Unknown Warrior. Although the silence and the Cenotaph have proved to be the enduring centrepiece of commemorations in the decades that followed, it was the Unknown Warrior who particularly captured the imagination on the day of his funeral in 1920. 
This was a commemorative innovation inspired not just by the scale of loss, but by the specific nature of the First World War. It was conceived after the initial plan for a permanent Cenotaph was drawn up: a response by the Dean of Westminster (based on former military chaplain, David Railton's idea) to the godless inscription on the Cenotaph, itself a non-Christian form of memorial considered appropriate for a multi-faith empire. Whereas the Cenotaph located in a civic space is derived from the Greek idea of an 'empty tomb', the Unknown Warrior provided a surrogate military funeral in the nation's foremost church (Gregory, 1994, p. 24; TNA WORK 20/1/3). The decision to not repatriate any of the war dead had denied their families a funeral and the impossibility of identifying so many who were 'missing' had deprived them even of the idea of a distant specific grave. But the Unknown Warrior, chosen at random from the missing on the Western Front, provided the tantalising prospect of a loved one returned home to the greatest honour the nation could bestow: burial at the heart of the imperial capital amidst the homage of a nation, an empire and its king (Lawson, 2008). King George V unveiled the permanent Cenotaph in Whitehall moments before the silence at $11 \mathrm{am}$, and then after the wreath laying the funeral procession made its way to Westminster Abbey for the interment of the Unknown Warrior. In the days that followed, thousands of people queued for hours to take their turn to visit the tomb ('London's Sunday Pilgrimage', 1920). The Unknown Warrior was the ultimate symbol of the destruction wrought on a mass army: an ordinary citizen elevated to the extraordinary. Both the Manchester Guardian and The Times stressed how commonplace this Unknown Warrior might have been, how unknowable, and thus how universal his identity was. As The Times put it, reflecting on the diversity of roles and ethnicities that had constituted the empire's war effort,

[he] may have been born to high position or to low; he may have been a sailor, a soldier, an airman; an Englishman, a Scotsman, a Welshman, an Irishman, a man of the Dominions, a Sikh, a Gurkha. No one knows ('Armistice Day, 1920').

Nonetheless, this was a seemingly egalitarian moment by an imperialist nation that remained otherwise profoundly hierarchical and conservative. Its function was to stabilise the status quo. The Times was particularly keen to stress the unifying nature of these rituals and hence the unity of the nation. In the preamble to its four-page supplement it commented:

Never before has there been such a proclamation, gladly made that we are all equal, all members of one body, or rather of one soul.

Then, revealing a political edge to this insistence on the nation's unity at a time when revolutions were underway elsewhere, the article continued,

this unanimity was not the sameness of the herd - we were lowered, but exalted to it. Implicit in it were all the higher thoughts and actions of men, all that man would be, not what he was in his animal past. A mob is incontinent, undisciplined, causeless in its rage and fear; but here all was planned and as in a great piece of music, and all of us were 
members of the orchestra; we had, each, his part in the expression of this grief and pride without discord or difference or failure.

In an orchestra, of course, everyone knows their place and follows the leader. Perhaps it was not coincidental then that Field-Marshal Earl Haig, former Commander-in-Chief of the British Expeditionary Force from 1915 to 1919, publicly linked 'our reverence and our gratitude for ever' to the dead with 'our obligations to living ex-Service men' (Haig, Long \& Trenchard, 1920). The Prince of Wales was also closely associated with this appeal ('Debt Of Honour', 1920). Noblesse oblige and the charitable donations of individuals took the place of adequate government pensions. This largely remained the case even after pensions reforms, the formation of the British Legion with Haig as its figurehead, and the launch of the poppy appeal to support returned men the following year. ${ }^{3}$ As Barr (2005) shows, such developments served to direct veterans' politics in a socially conservative direction.

The manner in which The Times and The Manchester Guardian reported on Armistice Day 1920 reflected their political stances. The Times' editorial dwelt on the righteousness of the war's cause and praised the unity of wartime and the way in which 'England' fought 'as a whole people, where all of us, women as well as men, were either fighting or helping others to fight'. This editorial concludes, 'The sorest heart that will beat before the Cenotaph or in the Abbey to-day would be sorer yet at the bare suggestion that this blood has been shed in vain' ('Armistice Day', 1920a). Whereas The Manchester Guardian was more focused on a present day in which 'the unity that we attained [during the war] we have not held'. This editorial continued 'it is a worse world now than it was before the war' in every regard ('Armistice Day', 1920b). The Times acted as a bastion of the present order, provided more specific information about the military arrangements for services, (see, for example, 'The Unknown Warrior', 1920a) and tended to stress order, loyalty and continuity. By contrast, The Guardian, as a progressive paper, was more willing to acknowledge political or social turbulence. For example, in reporting on Armistice Day in Ireland where the War of Independence was in an intensely violent phase, The Times focused on the reverence of observance in Dublin and the 'mood for peace' everywhere except the more inflamed areas ('In The Country', 1920). By contrast The Guardian used its Armistice Day editorial to decry the 'English' Government for reproducing 'crimes' within the United Kingdom akin to the 'Prussian' atrocities at Louvain during the 1914 invasion of Belgium ('Armistice Day', 1920b). Furthermore, the paper invested greater hopes in material change in the wake of the war. In its post-Armistice Day editorial, it described how the debt to the fallen should be repaid through 'the righting of ancient social wrongs, the willing surrender of possession or of privilege whose sacrifice may be needed for the common good' ('Yesterday's Celebration', 1920).

\footnotetext{
${ }^{3}$ Pensions for returned men only became a statutory right in 1921 . Haig was instrumental in the unification of a range of ex-servicemen's groups through the formation of the British Legion in the spring of 1921. It aimed to 'inculcate a sense of loyalty to the Crown, Community, State and Nation, [and] to promote unity amongst all classes'. (Barr, 2005, p. 124)
} 
In 1919 and 1920, a pattern of commemoration in Britain was established that met with huge popular support which continued throughout the interwar years. The addition of poppy sales by the British Legion in 1921 (drawing on the inspiration of Canadian poet John McCrae, and the charitable work of Moina Michael in America and Anna Guerin in France) to raise charitable funds for returned men completed the invention of the main traditions. By the end of the decade, the British Legion's factory was making 37 million individual poppies and 20,000 wreaths in preparation for Armistice Day ('37,000,000 Poppies, 1929). Such was the intensity of commemoration in the following two decades that it has attracted extensive historical research into its various facets including the design and erection of war memorials across the country, (Goebel, 2004; Heathorn, 2008; Macleod, 2010; Moriarty, 1991) the establishment of the Imperial War Museum, (Kavanagh, 1988) the work of the Imperial War Graves Commission, (Crane, 2013) and pilgrimages to overseas war graves for a privileged few (Lloyd, 1998). A hallmark of the commemorations was the tendency towards simplicity and the scope left for interpretation by the individual - epitomised by the silence and the absence of adornments on the Cenotaph. This has been central to their mass appeal and longevity. Whilst always retaining reverence for the 'Glorious Dead', the war has been interpreted and re-interpreted through ostensibly unchanging rituals at the same site. Thus, the analysis of these different newspapers in 1920 indicates the possibility of projecting differing meanings on to the commemorations. Working with a broader sample of sources, Gregory has charted this evolution from the patriotic rhetoric to justify the war in the early 1920s, to a more dour tone inflected by suffering and disillusionment towards the end of the decade. Where the war was once seen as a victory over Prussian militarism, by the early 1930s it was seen as an indictment of all militarism and was accompanied by relatively widespread pacifist sentiments (Gregory, 1994, pp. 24, 36, 122).

As diplomats worked to resolve the flawed legacy of the Treaty of Versailles and dictators sought to overturn it by force, the newspaper coverage of Armistice Day in the 1930s became more outward looking than at any other time, and more prone to use the occasion to reflect on international relations. This was most urgently the case in 1938. The Munich crisis that September had taken the country to the brink of renewed war with Germany. Poignantly, huge crowds expressed their fears by spontaneously making a pilgrimage to the Tomb of the Unknown Warrior whilst the crisis unfolded ('Prayer For Peace', 1938). A few weeks later, on Armistice Day, The Times, by this point a strong advocate of appeasement, took the lessons of the last twenty years to be 'the futility of a mere policy of force' ('Twenty Years After', 1938). By contrast, The Guardian reflecting on the Anschluss and the partition of 'Czecho-Slovakia' as well as developments in Abyssinia, Spain and China, concluded 'that men of goodwill in all countries have been defeated. Aggression has been found to pay'. In surveying the limited prospects of securing a lasting peace, its editorial framed its discussion within the potential for international relations to undermine the meaning of 1914-18:

the war that was to end war and leave a world safe for the peoples of that world was and is the only outcome that could justify the appalling sacrifices of the last struggle [...] the only basis that could fill the Pause of Armistice Day with something richer than regret or the recognition of valour as an end in itself ('Twenty Years Later', 1938). 
Lucy Noakes' recent work reveals further facets to Armistice Day in 1938: these contrasting public stances in the newspapers are the tip of the iceberg. Drawing on the Mass Observation archives to explore individuals' private thoughts on the day, she reveals the extent to which it was 'deeply contested, its multiple meanings often unmoored from remembrance of the dead'. Whilst for some it provided solace, others worried it was too distressing or anachronistic, even hypocritical. The official observance of Armistice Day was suspended from 1939 after the outbreak of the Second World War and Noakes' research shows how marginal it was to everyday life during the conflict (Noakes, 2015, pp. 340-2).

\section{Post-WW2 commemoration: decline towards irrelevance}

Official commemorations resumed on 11 November 1945. Inadvertently, but rather aptly, through a misunderstanding Manchester's Albert Square observed two silences that morning (Manchester's Remembrance', 1945). Ultimately, however, the official remembrance of 1939-45 became subsumed into the remembrance of 1914-18. The decision was taken to retain the traditions that had been established for commemorating the First World War, and to make only minor adjustments to acknowledge the later conflict. The Times argued that the two wars being commemorated 'were but separate parts of one, being waged against the same enemy in defence of the same principles and ennobled by the same spirit of self-sacrifice' ('Remembrance Day', 1945a). Yet whilst that newspaper sought to insist on the 'underlying unity of spirit' and 'eternal principles' which underpinned the occasion, The Guardian struck a more uneasy note at the restored day amidst changed circumstances, particular the shadow of the atom bomb: 'much of the material which surrounds us lends itself ill to the 'never again' mood of confidence that was more easily achieved by so many in 1918' ('Remembrance Day', 1945b).

The ceremonials continued the traditions established for the remembrance of the military dead of the First World War without recognition of the significant differences in the British experience of the Second World War. It remained a commemoration of military service, and hence of 'two generations of men and women who died in defence of freedom' ('The King At The Cenotaph', 1945). Women featured in two roles in 1945: as widows many of whom were dressed in black and, a new feature here, in uniform. The women's auxiliaries marched as part of the three branches of the armed services. Princess Elizabeth attended wearing an ATS uniform (Our London Staff, 1945). Nonetheless The Observer made a telling point in passing: 'Will there be a tomb of the Unknown Civilian?' ('Comment', 1945). Although the vague rhetoric employed in commemoration regarding 'the fallen' largely obscured the object of commemoration, this suggestion is a reminder that commemoration was aimed at sacrifice and service in the masculine mould of the armed forces, rather than the civilians whose work maintained the ability of the armed forces to fight in total war and who also incurred significant losses: 67,730 according to the Commonwealth War Graves Commission (n.d., p. 35). The People's War did not lead to the People's Commemoration. Instead, the Festival of Remembrance continued with extra petals added to the petal drop at the end which symbolised the Empire's dead ('Manchester's Remembrance', 1945), extra dates were carved into the Cenotaph, and the tradition continued as before (for further discussion of this period see Beadnell, 2018). 
During 1946 the decision was taken by James Chuter-Ede, the Home Secretary, in consultation with Church leaders and the British Legion to switch from Armistice Day to 'Remembrance Sunday' in the post war period. No alternative date linked to the Second World War commanded more emotional resonance (Gregory, 1994, pp. 215-221; Noakes, 2015, pp. 343-344; Richardson, 1998, p. 358). As a result the two minutes' silence interrupting the working week gradually ceased to be observed. This played its part in war commemoration's declining role in public affairs. Jay Winter, writing in 1999, argued,

Removed from daily life, [...] the ceremony lost meaning and atrophied. But even without such official intervention, it would inevitably have faded, as other tasks and other memories crowded out the earlier images and gestures. Once the memory of the bereaved was lost, once those who remembered the dead had themselves died, the original charge of the moment was lost, and the silence would become simply an absence - a void.

The assumption here is of the commemoration's association with the bereaved of the First World War. What also needs to be considered is the relationship between Remembrance Sunday and other subsequent wars. Thinking back to the 1938 assertion in The Times of the importance of continuity and a renewed relevance each year, what can be observed is the limited rhetorical or ceremonial efforts made to relate Remembrance Sunday to current events. This also played its part in the withering away of support for the ceremony.

Although the veterans and the bereaved of the Second World War were incorporated into the annual commemorations, with the exception of the tacit downgrading of the importance of the Unknown Warrior by the public, ${ }^{4}$ the commemorative traditions were not significantly adapted to acknowledge the different characteristics of 1939-45. The extent to which subsequent wars were incorporated and acknowledged was even more limited. In 1950, a gesture was made to incorporate those who had died in the Korean War since Britain had become involved earlier that year under the auspices of the United Nations. A small corner of the British Legion's Empire Field of Remembrance near Westminster Abbey, where individuals were able to plant wooden crosses in memory of a loved one, was designated for 'the fallen of the war in Korea' ('Remembrance Of Korea Dead', 1950). The falling petals at the end of the Festival of Remembrance were also reported to represent 'the Empire's dead in the two world wars and in Korea' ('Our London Correspondence', 1950). But this inclusivity was not continued thereafter. Only on one other occasion post-WW2 did the newspapers acknowledge a wider symbolism for these poppy petals when in 1952 they were said to represent all

\footnotetext{
${ }^{4}$ The annual public 'pilgrimage' to the tomb did not resume on a scale similar to that witnessed inter-war. In 1947, it was described as a 'thin stream' and it was noted in the newspaper for the last time in 1948. Individual visits to the tomb continued but they were no longer reported ('Abbey Remembrance', 1948; 'Remembrance In The Abbey', 1947).
} 
of the fallen since August 1914 up to and including Malaya and Korea ('Country Remembers Dead of Two World Wars', 1952). Belatedly, in 1980 there was a change in the printed order of service to include other wars. In that year the traditional prayer suggested to the crowd, 'We remember those who during the two wars made the great sacrifice' had a further element added, 'and all who have died in the service of their country' (Ezard, 1980). However, the intention was to cover not just those who had died on active duty in non-global wars but also civilian uniformed service personnel: 'police, nurses, ambulancemen, firemen and all other uniformed personnel who die "in the service of their country".' Should this change be read as welcome recognition of a dedicated group of civilians, or as a sign of growing unease at putting military sacrifice on a pedestal? The declining newspaper coverage of commemoration and alterations to the liturgy indicate it was the latter.

An earlier change to the form of service also suggests disquiet at the inherent militarism of the occasion. In 1968, the year of the fiftieth anniversary of the armistice, the churches had agreed on a change in the form of the service which diluted the emphasis on the dead of the two world wars by building in a focus on the theme of 'peace and reconciliation' (Staff Reporters, 1968). During the service at Westminster Abbey, the Venerable E.F Carpenter pinpointed the difficulty of the continuing relevance of the ceremony:

remembrance after the First World War was personal and intimate. While many people still felt this at the end of the Second World War, remembrance today had become more formal, intellectualized and historical (Staff Reporters, 1968).

Thus, whereas the interwar period saw occasional expressions of anxiety that the remembrance services would become irrelevant, newspaper articles in the post-WW2 period started to reflect a sense that they had already become irrelevant. Whilst The Times wondered in 1955 whether memories had grown dim amongst the survivors ('Have We Remembered?', 1955), a decade later there was an assumption of the younger generations' disinterest in the occasion (A Correspondent, 1965). This assumption developed in a broader context of a change in attitudes to warfare in general: the Campaign for Nuclear Disarmament was established in 1958, President Eisenhower warned against the military-industrial complex in 1961, and later the Vietnam War became a far more controversial war than any of its recent predecessors. Adding to the anti-war zeitgeist came specific critiques of the First World War itself. Influential books and plays such as Alan Clarke's The Donkeys (1961) and Joan Littlewood's Oh! What A Lovely War (1963) started to present the war as a mistake perpetrated by a bungling elite. Even cultural products that did not set out to take this editorial line, such as the BBC's epic 26 week documentary series The Great War (1964), were interpreted by its audience as revealing the horror and futility of war (Hanna, 2005; Todman, 2002 \& 2005).

Thus attitudes of pity and disdain in some quarters were bedfellows of the newspapers' disinterest in the ongoing commemorations of the world wars. The limited efforts to maintain the relevance of the ceremony's format were matched by a declining tendency to report on them in 
detail, and in particular to reflect on their relevance in editorials. There were only four occasions in the post war period when The Times published an editorial in relation to commemoration in November: 1946, 1955, 1957 and $1967 .{ }^{5}$ On other occasions in this period it published strongly Christian disquisitions on remembrance that treated war as an abstract concept. (A Correspondent, $1948,1950,1958,1960,1965)$. Editorials resumed (intermittently) from $1993 .{ }^{6}$ The Guardian was even less moved to opine on the subject, publishing only four editorials between the end of the war and the millennium: 1945, 1966, 1995 and 1998 ('Armistice Day misused', 1966; 'In memoriam', 1998; 'Remembrance Day', 1945b; 'Sound of silence', 1995). Indeed, its reporting of Remembrance Sunday became notably sparse. It was not reported on in The Guardian as an event in 1955, 1958, $1963-65,1967-79,1981,1983,1984,1988$ \& 1989, 1992 or 1993. What is apparent, then, between the end of the Second World War and the mid 1980s is a loss of interest in Remembrance Sunday and the commemoration of the two world wars, an outright ignorance of Britain's continuing military engagements around the world, and a loss of confidence in deriving meaning from military service and sacrifice.

\section{Remembrance Sunday since the 1980s}

From its nadir in the late 1970s there has been a partial revival of interest in commemorating military sacrifice in Britain. This is part of a wider phenomenon of the memory boom, a generalised growing interest in the past driven by a range of interlocking and complex factors. These include the political changes that unpicked the postwar settlement at the end of the Cold War. Growing affluence also played its part. It afforded more personal leisure time, a growing cultural sector, and more widespread tertiary education which provided both an audience for discussion of the past and an army of scholars both professional and amateur to investigate and reflect upon it. The rise of psychoanalysis and with it the uncovering of trauma and a willingness to share stories of victimhood was also an important driver of a phenomenon which is closely associated in the first instance with the testimony of Holocaust survivors (Winter, 2000).

Accordingly, what may be observed in the newspaper coverage of Remembrance Sunday of this period is the reconnection of the commemorative traditions with the personal stories of veterans, a turn away from abstract intellectualising towards recollection of lived experiences, and recognition of the lasting impact of war. The anniversaries of the end of the Second World War seem to have been crucial in inspiring a change in the newspaper coverage of the war, and then the commemoration itself. At the $40^{\text {th }}$ anniversary in 1985 the Ministry of Defence was persuaded to

\footnotetext{
${ }^{5}$ There was no editorial in 1936, and then between 1940 and 1993 the only years where an editorial was published in The Times around 11 November were as follows: 1942, 1943, 1945, 1946, 1955, 1957, and 1967.

${ }^{6}$ The Times published editorials on or near 11 November about commemoration in 1993, 1994, 1996-99, 2002, 2003, 2007, 2008, and 2011.
} 
fund a pilgrimage of 230 veterans and widows of the Second World War in Asia following a similar pilgrimage by relatives of those killed in the Falkland Islands in 1983. It may be speculated that the Falklands also paved the way for this change through the confident manner in which Margaret Thatcher chose to interpret the meaning of victory (Thatcher, 1982). The veterans' tour of momentous sites, including the River Kwai, Singapore, and the large 'Htauk-Kyan' war cemetery in Burma [Taukkyan War Cemetery, Myanmar] was covered extensively in both newspapers (Hamilton, 1985a, 1985b; Ezard, 1985a, 1985b, 1985c; Morris \& Hamilton, 1985). The reports are noteworthy as the first time that veterans' memories of the Second World War and the emotional intensity of their commemorative actions had been presented in a sustained fashion. Their importance was explained, personalised and demonstrated with historical context. John Ezard, accompanying the pilgrimage for The Guardian observed,

The Kwai experience has been intense - a funeral improperly delayed for 40 years but now properly enacted, complete with cards and posies from grandchildren. But it has also been an occasion of quiet breakfast conversations incandescent with remembered love (Ezard, 1985a).

The commemorative services were also noteworthy for the way in which they demonstrated that the 'comfortingly familiar' rituals could be adapted to multicultural circumstances. Describing a ceremony at Kranji war cemetery, Singapore, The Times journalist Alan Hamilton reported,

But the field was distinctly foreign with the old Scots lament The Flowers of the Forest played by Gurkha pipers, the prayers of Muslim, Buddhist, Hindu, Sikh, Jew and Zoroastrian intoned by exotic priests as well as an Indian Methodist bishop, and the names on the endless roll of the unburied, more Empire than British.

He went on to explain that Indian, Malay, Australian and New Zealand troops fought alongside the British in the region, and he highlighted the story of Louisa Harvey, a nurse who had been imprisoned and Murodo Cho, a Singaporean merchant navy purser. Whereas once attempts were made to broaden commemoration beyond death in the military towards 'peace and reconciliation' and civilian sacrifice in times of peace, here was a resumption of the focus upon the brute facts of war but with a broader appreciation of who was affected.

The 1985 trip to the Far East was part of a burst of pilgrimages and commemorations that served to dispel some of the ignorance and political suspicion of commemoration that had crept in to a broken relationship between civilians and the country's military heritage. In 1995 The Guardian journalist John Ezard reflected on participating in 'a remarkable 13-year era of war commemorations' that had started from the government-sponsored visit to the Falklands by widows and bereaved relatives in 1983 and culminated in huge public celebrations of the $50^{\text {th }}$ anniversary of VE and VJ Days attended by hundreds of thousands of people. Ezard's account reflected his fellow journalists' initial political suspicions of commemoration as a collapse into nostalgia or a cynical wheeze in a re-election campaign, as well as instances of a disconnect from military traditions such 
as his fellow journalist's ignorance of Elgar's elegiac Nimrod, a centrepiece to the musical programme at any such event. But the overall impact of Ezard's sustained involvement in these commemorations proved to be a deeper appreciation of the profound emotional impact for the individuals involved:

Most veterans still love their country and their thoughts are inevitably of the past. But buffers, saloon-bar bores and armchair generals seem to stay away from the pilgrimages. Instead what has emerged is a continuous revelation of how deep the springs of love, loss, duty and reflection run in human beings.

The voice which most sounds down the years for me is that of Mrs Annie Patterson, then aged 73 , of Newcastle, at the Somme $70^{\text {th }}$ anniversary in 1986 . She was alone but she suddenly cried out: "I have found you. I have found you at last."

It was her father's name on the Thiepval memorial (Ezard, 1995).

Newspaper coverage of Remembrance Sunday remained patchy until the early 1990s, but when it was reported on, it was increasingly likely to be accompanied by reports or references to individual experiences of war. For the $70^{\text {th }}$ anniversary of the Armistice, The Times reported on three old men's memories of the day. These encompassed the Western Front, the home front, and life on board ship (Hill, 1988). The Guardian told the story of Jacky Burgess who had joined the Auxiliary Territorial Service in 1942 and of women's war service more broadly (Ellison, 1988). Hence the newspaper reports also reflected a more diversified understanding of who was being commemorated. The tendency to focus on individual veterans reached its zenith after the $80^{\text {th }}$ anniversary saw the identification of Harry Patch (1898-2009) as one of the last surviving British soldiers from the Western Front (Webber \& Long, 2014, p. 273). Eleanor Bavidge has compared the focus on the last veteran to the Unknown Warrior, both reflecting a dialectic between the individual and the collective. Where once the universality of loss meant that everyone could find meaning in the unidentified individual, in the twenty-first century our distance from the realities of war meant that a focus on an identifiable person was 'an attempt to cut through the anonymity and the alienating effect of history and mass death' (Bavidge, 2009, p. 230). A society that no longer had direct connections to service and sacrifice in war valued these personal stories.

The search for the 'Last Tommies' reflected a remarkable growth in interest in war commemoration in the late 1990s. The fiftieth anniversaries of key dates in the Second World War were pivotal moments. In 1994, a political controversy over unduly frivolous plans to mark D-Day led by Peter Mandelson, a Labour MP with an astute appreciation of public opinion suggested an appetite for sombre commemoration (Leathley, 1994). The following year, encouraged by public support for the $50^{\text {th }}$ anniversaries of VE Day and VJ Day, the Royal British Legion reintroduced the 
tradition of observing the two minutes' silence on Armistice Day itself. The Times reported this as a contrast to the 1960s and 70s when 'patriotism became unfashionable', whereas The Guardian whilst supporting the renewal of the silence acknowledged that some still viewed military commemorations as 'distasteful' (Frost, 1995; 'Sound of silence', 1995). By 1998, an extended article free from similar qualms in The Guardian reflected on the growing fascination with the war across society: in schools, films, battlefield tours, re-enactments, family history research, veterans, and the campaign to pardon those shot-at-dawn ('All our yesterdays', 1998). This was the memory boom in full flight.

In this period, both the format of the commemorations and their coverage had become steadily more inclusive. The 1998 commemorations, for example, included Falklands veterans marching as a formal group for the first time, Gulf War veterans, and the Bevin Boys: civilians who had been conscripted to work in the mines in the Second World War (Evans, 1998). From 2000, the British Legion altered the commemorative service to acknowledge overseas servicemen and women, and other faiths as well as allowing civilians to join the parade. Hence there was official representation from the Sikh, Buddhist, Hindu, Muslim and Greek Orthodox faiths and the First World War Pardons Association joined the parade for the first time (Branigan, 2000; Ward, 2000). The commemorations, whilst retaining their core traditions, were thus the subject of modest changes to better reflect the breadth of society and honoured a fuller sense of service in wartime. Graham Stewart writing for The Times in 2000 could thus praise remembrance of 'the Armed Forces of the Empire' as 'a pillar of the development of a multicultural Britain'. Resurrecting a familiar theme from earlier Times articles on commemoration, he wrote that during the silence, 'Britain experiences its one moment of genuine unity' (Stewart, 2000). The previous year had seen the establishment of the Scottish Parliament, and, interestingly, similar sentiments regarding the unifying power of commemoration had also been expressed in the newspaper in the wake of the 1978 failed referenda on devolution in Scotland and Wales (Martin, 1980). This was also the era of the Good Friday Agreement (signed in April 1998), the conclusion of the peace process in Northern Ireland. Yet the veterans of Operation Banner in the Province - the most sustained deployment of British soldiers post-WW2 - have never marched as a formal group on Remembrance Sunday because 'The Troubles' is not designated as a conflict or war. Yet, if we consider that The Troubles were the most significant contestation of the unity of the UK post-WW2 and that service and deaths of British military personnel in Northern Ireland have not been fully and formally incoporated into national commemoration, it seems that the remembrance of death remains closely linked to the imperative towards national unity. The Troubles remains a highly-charged political memory.

Stewart's 2000 article considered that commemoration avoided being 'contentious and divisive', whilst in the same year The Guardian noted that Armistice Day was no longer 'an occasion for spirited public debate about war and peace'. All the same, in contrast to its conservative competitor, it preferred to leave room for multiple interpretations and hopes for change: during the silence 'each one of us can use it in our own way, to remember the past - or to resolve to make a different future' ('Remember this', 2000). The sense at this point in time that arguments over war and peace were over, in retrospect, seem redolent of a brief window between the collapse of the 
Soviet Union in 1991 and the 9/11 attacks in 2001: halcyon days when the big political questions were resolved and grand sentiments were drained of their urgency. A period when the Royal British Legion might win a marketing award or Craig Brown's alter ego Bel Littlejohn could write a parody of making commemoration relevant under Blairism with the headline 'We will revamp them' (Littlejohn, 2000; Richardson, 1998, p. 362).

Thereafter, a renewed period of warfare in Iraq and Afghanistan between 2001 and 2014 made the commemoration of military sacrifice all too relevant once more. The public discussion of these wars often drew on First World War allusions to shape the debate (Wilson, 2014), and the government sought to legitimate the war in Afghanistan through the remembrance service for Harry Patch. Most strikingly, new rituals were forged in Wootton Bassett in tribute to the repatriation of the war dead from Afghanistan that included a minute's silence, creating as McCartney notes, an imaginative link between the two wars (McCartney, 2014, p. 312; see also, Jenkings, Megoran, Woodward, \& Bos, 2012). Whereas the newspaper coverage of postwar November commemorations had tended to avoid acknowledging contemporary military service and death in action, from 2005 the link started to be made. That year, the annual poppy appeal was led by a widow of a soldier who had died in Iraq, Private Johnson Beharry VC (age 25) was reported on in the same breath as Henry Allingham (age 109), and the Defence Secretary John Reid commented 'Armistice Day not only commemorates the many heroic acts and great sacrifices made during both world wars, it also allows us to thank those currently on active service' (Evans, 2005; The Guardian, 2005, my emphasis). By 2010 The Times was able to opine of the ceremony at the Cenotaph:

To stand in Whitehall, to see the Queen lay her wreath at the Cenotaph, to watch the veterans march past with their berets and their medals, is to be wrapped up in the narrative of recent British military history. From the SWW to Afghanistan, by way of Korea, Suez, the Falklands and Iraq, no conflict of the past 100 years went unmarked (Low, 2010).

Meanwhile, Prince William laid a wreath in Afghanistan marking a private connection to the loss of personal friends in war and all of Britain's war dead which read 'For Jo, Lex and all those who have made the ultimate sacrifice for our country'.

The increasing prominence of commemoration within public life did not go uncriticised. From the left, there was a concern that the social pressure to wear the symbol of remembrance amounted to 'poppy fascism' (White, 2010) and from within the military establishment, using The Times as its mouthpiece, there was a concern expressed that commemoration had become 'mawkish' and with its celebrity endorsements, merely the subject of 'recreational grief' and 'tearstained sentimentality' (Linklater, 2010; Coghlan, 2010). Nonetheless, the military had played its part in such developments by seeking to strengthen its own place in British public life through the invention of 'Armed Forces Day' from 2006 (initially as 'Veterans Day'), and as Todman argues this has combined with the efforts of military charities, such as Help for Heroes, to fundraise and with those 'interested in celebrating a martial, imperial British identity as part of a clash of civilizations 
with extreme Islam'. It was within this context that David Cameron announced it would spend $f 50$ million on the centenary. The commemorations would, argued Cameron, say 'something about who we are as a people' (Todman, 2016, p. 521) at the very moment when the union of nations within the United Kingdom and the UK's relationship with the European Union were reaching crisis point (Mycock, 2014).

In consequence of the unprecedented spending on the centenary - the government didn't organise official ceremonies to mark the $50^{\text {th }}$ anniversary in 1968 (Todman, 2016, pp. 520-1) - the remembrance of the First World War has been more active and energetic, more widespread and unavoidable since 2014 than at any time since WW2. The BBC has produced content tailored to each locality, the Heritage Lottery Fund has made grants to projects across the country, 14-18 Now has commissioned arresting arts projects, the Imperial War Museum has been refurbished, children from every secondary school have been taken to the battlefields, and the government has organised commemorative services for the key anniversaries. The commemoration of the First World War has overflowed far beyond its habitual November confines. Remembrance of such scope and scale has had ample space in which to acknowledge an ever more diverse array of military service during the First World War, including of forces from the British Empire, as well as the wider impact of the war upon civilians (see, www.1914.org; AHRC, 2018). This appears to have had the effect on the November newspaper coverage of Remembrance Sunday and Armistice Day of tightening the focus on the politics of the present day. For example, the dominant story of the coverage in 2015 focused on whether the newly-elected Labour leader, Jeremy Corbyn, had showed sufficient respect at the Cenotaph service. As a pacifist with a long track record of opposing military intervention, his words and deeds were carefully scrutinised, revealing the inherent militarism and nationalism of the event. There were strong echoes here of the scrutiny afforded to an earlier newly-elected left-wing Labour leader. In 1981, Michael Foot allegedly scruffy coat and shoes, and his failure to bow when laying a wreath was widely commented on (Horsnell, 1981). Whereas its militaristic aspects had once undermined widespread support for commemoration, the political limits of non-conformity with military standards were well established in 1981, and 2015 confirmed that suspected failure to show a due measure of patriotism could be instrumentalized in party politics (Guardian staff, 2015; Low, 2015). The time-honoured traditions of the November commemorations had been maintained, but were rendered more relevant during the centenary than they had ever been post-WW2.

The profound and widespread grief caused by the scale of loss in the First World War provoked the invention of a new set of commemorative traditions that have been observed with only minor changes for a century. Yet the way in which these traditions have been interpreted have changed over time: as Roy Foster put it, 'commemoration is, of course, always present-minded' (Foster, 2001, p. 68). Furthermore, this present-mindedness leaves the interpretation of relevance open to political influence. This article has shown that a right-leaning newspaper and a left-leaning newspaper consistently drew dissimilar interpretations of commemoration: The Times tended to emphasise unity and continuity particularly in the inter-war period, whereas The Guardian was more frank about political turbulence and later, more uneasy about the militarism it perceived in commemoration. They did so within a shared broader social and political context in which 
commemoration took place. Over time, the emotional charge of the rituals diminished and the political relevance of remembering the 'war to end all wars' was undermined by the renewal of conflict between 1939 and 1945 . Thereafter, the limited attempts to maintain its relevance to the changing nature of conflict contributed to the growing rift between civil society and those directly affected by sacrifice in war. However, the memory boom that emerged from the 1980s gradually served to reinstall individual stories at the heart of collective remembrance. A more inclusive version of the significance of commemoration emerged in a period of renewed but controversial warfare. The centenary has served to amplify these trends at a time of crisis in Britain's national identity. The continued commemoration of our military heritage has thus provided a means by which to reflect on the past through the prism of present day concerns.

Archival sources

The National Archives (TNA), Kew: WORK 20/1/3 ‘Cenotaph, Whitehall: general arrangements in respect of the unveiling ceremony \& burial of the unknown warrior November 1920'

37,000,000 Poppies. (1929, October 26). The Manchester Guardian, p. 24.

A Correspondent. (1948, November 6). Remembrance Sunday. The Times, p. 6.

A Correspondent. (1950, November 11). Remembrance Day. The Times, p. 8.

A Correspondent. (1958, November 8). Remembrance Day. The Times, p. 8.

A Correspondent. (1960, November 12). The Love That Reconciles. The Times, p. 8.

A Correspondent. (1965, November 13). Remembrancetide. The Times, p. 12.

Abbey Remembrance. (1948, November 8). The Times, p. 2.

AHRC. (2018, April 24). 'World War One and its Legacy - Arts and Humanities Research Council' [webpage]. Retrieved from https://ahrc.ukri.org/research/fundedthemesandprogrammes/worldwaroneanditslegacy All our yesterdays. (1998, November 7). The Guardian.

Armistice Day. (1920a, November 11). The Times, p. 15.

Armistice Day. (1920b, November 11). The Manchester Guardian, p. 8.

Armistice Day, 1920. (1920, November 12). The Times, (i), i+.

Armistice Day misused. (1966, November 14). The Guardian, p. 8. 
Barr, N. (2005). The lion and the poppy: British veterans, politics, and society, 1921-1939. Westport, Conn.; London: Praeger.

Bavidge, E. (2009). The public private: the Last Veteran. Journal of War \& Culture Studies, 2(2), 225236.

Beadnell, H. (2018). Honouring their Comrades: Second World War veterans and commemorative events. Presented at the Remember Me: The Changing Face of Memorialisation conference, Hull.

Branigan, T. (2000, November 13). Poppy day marches into a new century. The Guardian, p. 7.

Cannadine, D. (1981). War and Death, Grief and Mourning in Modern Britain, in: Whaley, J. (Ed.), Mirrors of Mortality: Studies in the Social History of Death. London: Europa Publications.

Coghlan, Tom. (2010, November 13). General fears 'mawkish' view of military. The Times, p. 3.

Comment. (1945, November 11). The Observer, p. 4.

Commonwealth War Graves Commission. (n.d.). Annual Report 2015-16

Connelly, M. (2002). The commemoration of the Great War in the City and East London, 1916-1939. Woodbridge, Suffolk: The Boydell Press

Country Remembers Dead of Two World Wars: Weather Unkind to Outdoor Services. (1952, November 10). The Manchester Guardian, p. 10.

Crane, D. (2013). Empires of the dead: how one man's vision led to the creation of WW1's war graves. London: William Collins.

Debt Of Honour. (1920, November 9). The Times, p. 12.

Edele, M., \& Gerwarth, R. (2015). The Limits of Demobilization: Global Perspectives on the Aftermath of the Great War. Journal of Contemporary History, 50(1), 3-14.

Ellison, J. (1988, November 10). A woman's part in Hitler's downfall: Women and the war. The Guardian, p. 21.

Evans, Michael (1998, November 9). Bevin Boys pay their public tribute at last. The Times, p. 1. Evans, Michael. (2005, November 12). The fallen remembered on two fronts. The Times, p. 41. Ezard, J. (1980, November 10). Unspoken words widen service's embrace. The Guardian, p. 26. Ezard, J. (1985a, November 9). Bridge of sorrows beside the River Kwai. The Guardian, p. 17. Ezard, J. (1985b, November 11). Pilgrims mark Far East fallen. The Guardian, pp. 1-2.

Ezard, J. (1985c, November 12). Pilgrims end 'dream of lifetime'. The Guardian, p. 7.

Ezard, J. (1995, August 19). Victory commemorations help to restore collective memory: John Ezard on a remarkable era which has seen remembrance turn into a way of life. The Guardian, p. 8.

First World War Centenary. (2018, April 24). 'First World War Centenary. Take part in this global commemoration 2014-18' [website]. Retrieved from www.1914.org. 
Frost, Bill. (1995, November 11). 'Big Ben seemed to boom louder than ever before'. The Times, p.

10.

Foster, A.-M. (2018). A Continuity of Mourning, c. 1899-1939. Presented at the Remember Me: The Changing Face of Memorialisation conference, Hull.

Foster, Roy. (2001). Remembering 1798. In. Ian McBride (ed.), History and Memory in Modern Ireland (pp. 67-94). Cambridge: Cambridge University Press

Hill, George (1988, November 9). The day that peace broke out. The Times, p. 12.

Goebel, S. (2004). Re-membered and Re-mobilized: the 'Sleeping Dead' in Interwar Germany and Britain. Journal of Contemporary History, 39(4). 487-501.

Gregory, A. (1994). The Silence of Memory: Armistice Day 1919-1946. Oxford.

Gregory, A. (2008). The last Great War: British society and the First World War. Cambridge:

Cambridge University Press.

Guardian staff. (2015, November 9). Jeremy Corbyn criticised for not bowing deeply enough at Cenotaph. The Guardian.

Haig of Bemersyde, Long \& Trenchard, (1920, November 11). Our Debt To The Living. The Times, p. 15.

Hamilton, Alan. (1985a, November 9). Burma Railway survivors and widows pay homage. The Times, p. 6.

Hamilton, Alan. (1985b, November 12). Ceremony in the jungle. The Times, p. 2.

Hanna, E. The Great War on the small screen: representing the First World War in contemporary Britain. Edinburgh: Edinburgh University Press.

Have We Remembered? (1955, November 11). The Times, p. 9.

Heathorn, S. J. (2008). The Civil Servant and Public Remembrance: Sir Lionel Earle and the Shaping of London's Commemorative Landscape, 1918-1933. 20th Century British History, 19(3), 259-287. Holbrook, C. (2014). Anzac: the unauthorised biography. Sydney: NewSouth Publishing. Horsnell, Michael. (1981, November 9). The Times Diary. A casual Foot, unbowed at the Cenotaph. The Times, p. 10.

In memoriam: Silence, if you please. (1998, November 11). The Guardian, p. 19.

In The Country. (1920, November 12). The Times, p. iv.

Inglis, K. S. (1965). The Anzac tradition. Meanjin Quarterly, (100), 25-44.

Inglis, K. S. (1992). War Memorials: Ten Questions for Historians. Guerres Mondiales et Conflits Contemporains, (167), 5-21.

Inglis, K. S. (1998). Sacred Places: War Memorials in the Australian Landscape (first paperback edition 2001). Carlton South, Victoria: Melbourne University Press. 
Jalland, Pat (2010). Death in War and Peace. Loss and Grief in England, 1914-1970. Oxford: Oxford University Press.

Jenkings, K. N., Megoran, N., Woodward, R., \& Bos, D. (2012). Wootton Bassett and the political spaces of remembrance and mourning: Wootton Bassett and the political spaces of remembrance. Area, 44(3), 356-363.

Jenkinson, J. (2008). Black Sailors on Red Clydeside: Rioting, Reactionary Trade Unionism and Conflicting Notions of 'Britishness' Following the First World War. Twentieth Century British History, 19(1), 29-60.

Kavanagh, G. (1988). Museum as Memorial: The Origins of the Imperial War Museum. Journal of Contemporary History, 23(1), 77-97.

King, A. (1998). Memorials of the Great War in Britain. The Symbolism and Politics of Remembrance. Oxford / New York: Berg.

Lawson, T. (2008). 'The Free-Masonry of Sorrow'? English National Identities and the Memorialization of the Great War in Britain, 1919-1931. History and Memory, 20(1), 89-120. Leathley, Arthur. (1994, April 20). Scrap D-Day revels, Legion tells Major. The Times, p. 1.

Linklater, Magnus. (2010, November 15). It is demeaning to treat war like a TV reality show. The Times, p. 26.

Littlejohn, B. (2000, November 17). We will revamp them. The Guardian, p. 25.

Lloyd, D. W. (1998). Battlefield tourism : pilgrimage and the commemoration of the Great War in Britain, Australia and Canada. Oxford: Berg.

London's Sunday Pilgrimage. The National Tribute Goes on. Queues at the Abbey and Cenotaph. (1920, November 15). The Manchester Guardian, p. 7.

Low, Valentine. (2010, November 15). Prince William makes a surprise visit to Afghanistan to honour fallen comrades. The Times (London), p. 10.

Low, Valentine. (2015, November 11). Times read at Cenotaph to honour lost generation. The Times (London), p. 17.

Macleod, J. (2002). The fall and rise of Anzac Day: 1965 and 1990 compared. War \& Society, 20(1), 149-168.

Macleod, J. (2010). Memorials and location: local versus national identity and the Scottish National War Memorial. Scottish Historical Review, 89, 73-95.

Macleod, J. (2015). Gallipoli. Oxford: Oxford University Press.

Manchester's Remembrance: Symbolism of Two 'Silences' in Albert Square. (1945, November 12). The Manchester Guardian, p. 3. 
Martin, Christopher (1980, November 8). Remembrance Sunday and the sense of national unity. The Times, p. 16.

McCartney, H. B. (2014). The First World War soldier and his contemporary image in Britain. International Affairs, 90(2), 299-315.

Moriarty, C. (1991). Christian iconography and First World War Memorials. Imperial War Museum Review, 6, 63-75.

Morris, Rupert \& Alan Hamilton. (1985, November 11). Queen leads the Commonwealth's tribute to war dead. The Times, p. 36.

Mosse, G. L. (1979). National Cemeteries and National Revival: The Cult of the Fallen Soldiers in Germany. Journal of Contemporary History, 14(1), 1-20.

Mycock, Andrew. (2014) The Politics of the Great War Centenary in the United Kingdom. In S. Sumartojo and B. Wellings (eds), Nation, Memory and Great War Commemoration (pp. 99118). London: Peter Lang

Noakes, L. (2015). A broken silence? Mass Observation, Armistice Day and 'everyday life' in Britain 1937-1941. Journal of European Studies, 45(4), 331-346.

Our London Correspondence. (1920, November 11). The Manchester Guardian, p. 8.

Our London Correspondence (1950, November 13). The Manchester Guardian, p. 4.

Our London Staff. (1945, November 12). Remembrance of Two Wars: Cenotaph's Service First 'Silence' for Seven Years. The Manchester Guardian, p. 5.

Prayer For Peace. (1938, September 30). The Times, p. 14.

Remember this: Time to consider both past and present. (2000, November 11). The Guardian, p. 27. Remembrance Day. (1945a, November 10). The Times, p. 5.

Remembrance Day. (1945b, November 12). The Manchester Guardian, p. 4.

Remembrance In The Abbey. (1947, November 10). The Times, p. 2.

Remembrance Of Korea Dead. (1950, November 9). The Times, p. 3.

Richardson, Matthew. (1998). A Changing Meaning for Armistice Day. In H. Cecil (Ed.), At the Eleventh Hour (pp. 347-364). Barnsley: Pen and Sword.

Sound of silence: People want to remember: so let them. (1995, November 13). The Guardian, p. 12. Staff Reporters. (1968, November 11). Remembrance Day at the Cenotaph. The Times, p. 5. Stewart, Graham. (2000, November 11). Two minutes of silence that tell us Britain truly has a National Day. The Times, p. 28.

Thatcher, M. (1982, July). Speech to Conservative Rally at Cheltenham. Cheltenham Racecourse, UK. Retrieved from https://www.margaretthatcher.org/document/104989

The Glorious Dead. (1919). The Times, (12), 12. 
The Guardian. (2005, November 12). In praise of ... :Remembrance, The Guardian, p. 34.

The King At The Cenotaph. (1945, November 12). The Times, p. 4.

The Silent Commemoration: Yesterday's National Tribute to the Men Who Fell Striking Scenes in the Great Cities. (1919, November 12). The Manchester Guardian, p. 7.

The Unknown Warrior. (1920a, November 10). The Times, p. 12+.

The Unknown Warrior. (1920b, November 11). The Times, p. 15+.

Todman, Dan. (2002). The Reception of The Great War in the 1960s. Historical Journal of Film, Radio and Television, 22(1), 29-36.

Todman, Dan. (2005). The Great War: Myth and Memory. London: Hambledon.

Todman, Daniel. (2016). 'Something About Who We Are as a People': Government, Media, Heritage and the Construction of the Centenary. Twentieth Century British History, 27(4), 518-523.

Twenty Years After. (1938, November 11). The Times, p. 15.

Twenty Years Later. (1938, November 11). The Manchester Guardian, p. 10.

Ward, D. (2000, November 10). Battle for recognition Shamed soldiers acknowledged. The Guardian, p. 5.

Webber, N., \& Long, P. (2014). The last post: British press representations of veterans of the Great War. Media, War \& Conflict, 7(3), 273-290.

White, Michael. (2010, November 5). No one should be given a white feather for not wearing a poppy. The Guardian.

Wilson, R. (2014). Sad shires and no man's land: First World War frames of reference in the British media representation of the Iraq and Afghanistan Wars. Media, War \& Conflict, 7(3), 291-308.

Winter, J. (2000). The Generation of Memory: Reflections on the 'Memory Boom' in Contemporary Historical Studies. Bulletin of the German Historical Institute, (27), 69-92.

Winter, J. (2006). Remembering war: the Great War between memory and history in the twentieth century. New Haven: Yale University Press.

Winter, J. M. (1995). Sites of Memory, Sites of Mourning: The Great War in European Cultural History. Cambridge: Cambridge University Press.

Winter, Jay. (1999). Remembrance and Redemption. Harvard Design Magazine:, 9, [online]. http://www.harvarddesignmagazine.org/issues/9/remembrance-and-redemption Yesterday's Celebration. (1920, November 12). The Manchester Guardian, p. 8. 
